\title{
Концепція «м'якої сили» в контексті зовнішньополітичної стратегії України
}

\author{
Коротков Д. С., Харківській національний економічний університет ім. С. Кузнеця
}

У статті досліджено основні принципи та концептуальні підходи поняття «сили». Відзначається, що сучасні глобалізаційні процеси у світі (політичні, економічні) впливають і на появу нових дефініцій сили. Аналізуються основні теоретичні концепції міжнародних відносин - «жорстка сила» й «м'яка сила» та можливості їх використання у зовнішньополітичної стратегії України. Вивчаються причини появи концепції «м'якої сили», серед яких: кінець «холодної війни»; формування багатополярної міжнародної системи. Це призводить до зміни природи самої сили, в основному роблячи стратегію «м'якої сили» більш потенційною. Звертається увага на актуальність проблеми сутності концепції «м'якої сили» та можливості ії̈ використання у зовнішній політиці України в ії науковому політичному дискурсі. Анексія Криму 2014 р. та військовий конфлікт із Росією вплинув на майбутнє впровадження цієї концепції, потенціал якої вже вичерпаний. «Помаранчева революція» 2004 р. та «Революція гідності» 2014 р. - це знакові події сучасної України та головний інструментарій стратегії «м'якої сили». Ці явища сформували позитивний імідж України в країнах євро простору, і є необхідність обмеження використання цієї концепції (інформаційно та фінансово) та надавати пріоритет іншій - «жорсткій силі». Стосовно України інструментарії привабливості економічної моделі розвитку не є ефективними та поки ще безперспективні. Вторинні ефекти внутрішніх політичних та економічних потрясінь, анексії Криму та військових дій на Донбасі поширилися на більшість секторів вітчизняної економіки. Відзначається, що в контексті культурно-ціннісної привабливості для того, щоб задіяти весь іміджевий потенціал нашої держави, необхідні продумана державна інформаційна політика й чітко спланована брендингова кампанія, а це потребує часу та значних фінансових витрат. Події в Україні показують, що для забезпечення своєї національної безпеки для держав «другого ешелону» пріоритетним є формування військової могутності.

Ключові слова: сила; «м'яка сила»; «жорстка сила»; міжнародні відносини; політичні цінності; демократія; громадянське суспільство

\section{The concept of «soft power» in the context of Ukrainian strategy of foreign policy}

\section{Korotkov D. S., S. Kuznets Kharkiv National University of Economics}

This article explores the basic principles and conceptual approaches to the concept of «power». Modern globalizational processes in the world (political, economic) influence the emergence of new concepts of power. The basic theoretical concepts of international relations - «hard power» and «soft power» and the possibility of using them in Ukrainian foreign policy are under consideration. The causes of emergence of the «soft power» concept is studied in the article. Among the mentioned causes we examine the end of «Cold War» and formation of multipolar international system. It brings us to the changes of the nature of the power itself and makes the strategy of «soft power» more potential. The attention is drawn to the relevance of the essence of the «soft power» concept and possibility of its usage in Ukrainian foreign policy, in its political scientific discussions. The annexation of the Crimea in 2014 and the military conflict with Russia influenced the future implementation of this concept. The potential of the «soft power» concept in Ukraine is already exhausted. The «Orange Revolution» in 2004 and «Revolution of Dignity» in 2014 are the symbolic events of modern Ukraine and the main tools of the «soft power». These events formed a positive image of Ukraine in Europe. It is necessary to restrict (financially and informationally) the usage of this concept and give priority to the «hard power». Concept of «soft power» is only effective in the countries with significant military and economic potential.

With regard to Ukraine, the tools of the attractiveness of the economic model of development are not effective and are still unpredictable. The secondary effects of internal political and economic upheavals, the annexation of the Crimea and hostilities in the Donbas spread to most sectors of the national economy. It is noted that in the context of cultural and value attraction in order to use the whole image potential of our state, we need a well-thought out state information policy and a clearly planned branding campaign, which takes time and considerable financial expenses. Ukraine show that in order to ensure its national security for the 'second-tier' states the development of its own military force should be on a priority basis.

Keywords: power; «soft power»; "hard power»; international relations; political values; democracy; civil society 


\title{
Концепция «мягкой силы» в контексте внешнеполитической стратегии Украины
}

\author{
Коротков Д. С. Харьковский национальный эконмический університет им. С. Кузнеца
}

В статье исследованы основные принципы и концептуальные подходы понятия «силы». Отмечается, что современные глобализационные процессы в мире (политические, экономические) влияют и на появление новых дефиниций силы. Анализируются основные теоретические концепции международных отношений «жесткая сила» и «мягкая сила» и возможности их использования в внешнеполитической стратегии Украины. Изучаются причины появления концепции «мягкой силы», среди которых: конец «холодной войны»; формирования многополярной международной системы. Это приводит к изменению природы самой силы, в основном делая стратегию «мягкой силы» более потенциальной. Обращается внимание на актуальность проблемы сущности концепции «мягкой силы» и возможности ее использования во внешней политике Украины в ее научном политическом дискурсе. Аннексия Крыма 2014 и военный конфликт с Россией повлиял на будущее внедрение и использование этой концепции, потенциал которой уже исчерпан. «Оранжевая революция» 2004 и «Революция достоинства» 2014 это знаковые события современной Украины и главный инструментарий стратегии «мягкой силы». Эти явления сформировали позитивный имидж Украины в странах европространства, и требуются ограничения использования этой концепции (информационно и финансово) и предоставление приоритета другой «жесткой силе». Утверждается, что концепция «мягкой силы» эффективна только в странах со значительным военным и экономическим потенциалом.

Что касается Украины, инструментарии привлекательности экономической ее модели развития не эффективны и пока еще бесперспективны. Вторичные эффекты внутренних политических и экономических потрясений, аннексии Крыма и военных действий на Донбассе распространились на большинство секторов отечественной экономики. Отмечается, что в контексте культурно-ценностной привлекательности для того, чтобы задействовать весь имиджевый потенциал нашего государства, необходимы продуманная государственная информационная политика и четко спланированная брендинговая кампания, а это требует времени и значительных финансовых затрат. События в Украине показывают, что для обеспечения своей национальной безопасности для государств «второго эшелона» приоритетным является формирование военной мощи.

Ключевые слова: сила; «мягкая сила»; «жесткая сила»; международные отношения; политические иенности; демократия; гражданское общество

\section{Постановка проблеми.}

Актуальність теми обумовлена подіями стосовно військового, економічного та дипломатичного конфлікту між Україною та Росією на початку 2014 р. Російська військова агресія змушує переглянути основи як військової доктрини України, так і впровадження нових концепцій у зовнішньополітичну стратегію України. Тема використання стратегії «м'якої сили» у міждержавних відносинах та їі сутності дуже популярна й актуальна в останні роки у науковому дискурсі України. Але питання можливості та необхідності використання цієї стратегії нашою державою в сучасних умовах залишається відкритим.

\section{Аналіз досліджень і публікацій.}

Дослідження проблематики концепції «м'якої сили» знайшло своє відображення в працях представників різноманітних наукових течій. Вагомий внесок у розробку цієї проблеми зробили такі зарубіжні вчені, як Дж. Най (мол.), Дж. Акшай, Р. Армітідж, Зб. Бжезинський, Р. Кейган, Р. Кеохейн, А. Коен, М. Лібіцкі,
С. Люкс, Дж. Меттерн, У. Оуенс, I. Пармар, Н. Сноу, С. Уолт, Г.Филимонов, М. Фрейзер, Ф. Фукуяма, П. ван Хем, К. Хілл, С. Цатурян, I. Чихарєв та ін.

Про можливість застосування «м'якої сили» у зовнішньополітичному курсі України вітчизняні дослідники заговорили порівняно нещодавно. Відтак теоретичний рівень вивчення цього питання ще досить незначний у зіставленні 3 США, Китаєм чи РФ і зосереджений у працях А. Дівончука, В. Головченка, В. Горбатенка, А. Луценко, О. Михайловської, Н. Нікулішин, В. Пантелєєва, I. Слісаренко, Я. Турчин, М. Цюрупи, О. Шевчука, С. Шергіна, I. Хижняк, В. Цимбалістого, Л. Чекаленка, С. Юрченка та ін.

Метою дослідження є визначення основних проблем та аналіз пріоритетів використання концепції «м'якої сили» у зовнішній політиці України.

Виклад основного матеріалу.

Поява нових концептів та їх впровадження у дискурсивному полі різних наук представляє великий інтерес для дослідників. Концепт «м’яка 
сила» (soft power) був запроваджений американським політологом Дж. Найєм і викликав значну зацікавленість в наукових колах різних країн. Необхідно зазначити, що дослідник стосовно саме теорії не сформував чогось принципово нового. Різні способи впливу на свідомість, методи ненасильницької обробки владних та інших груп відомі давно: про них у різний час писали Н. Макіавеллі i французькі енциклопедисти Г. Торо та М. Ганді, Т. Лірі і Р. Вілсон та ін. Досягнення Дж. Ная полягає в тому, що він зумів не тільки концентровано і ємко описати природу, роль та значення «м'якої влади», яка зіграла певну роль в «холодній війні», а й визначити іiі воістину необмежені можливості у XXI столітті. I ця робота триває: як відомо, в даний час Дж. Най формує порядок «розумної влади» для нинішньої адміністрації Білого дому, розуміючи iï як «здатність об'єднувати в різних контекстах жорсткі і м'які ресурси влади в успішні стратегіï» $[7$, c. 45$]$.

Необхідно підкреслити, що основу концепту «м'яка сила» складає поняття «сила». Намагання пояснити відносини між людьми 3 позиції сили існували, напевно, з часів первіснообщинного ладу. Сучасні тенденції світового розвитку сприяють виникненню нових параметрів сили, на які раніше не акцентували увагу. Дійсно, сучасна теорія та практика міжнародних відносин пропонує різні підходи стосовно дефініції «сила», але здебільшого під силою розуміють можливість сильнішого актора нав'язати свою волю слабшим, тим самим змінюючи характер відносин на свою користь. Прихильники концепції політичного реалізму (Р. Гилпін, Д. Зінгер, Г. Кіссінджер, Г. Моргентау, А. Органський, Б. Рассет, А. Уолферс та ін.) намагаються зобразити силу як певну величину, яку можна обчислити. Критики реалізму вважають, що такі характеристики як культура, національна мораль чи якість дипломатії, в тому числі і державного керівництва, не можна врахувати достовірно, а обчислення будуть грунтуватися на суб'єктивних оцінках, а не на об'єктивних, математично обгрунтованих результатах [4, с. 194].

Провідні американські політологи Дж. Най та Р. Кеохейн досліджують сутність «сили» вже в контексті структуралістського підходу та виводять її на основі ідей, вироблених у рамках теорії взаємозалежності. Вони вважають, що силу держави не можна прирівнювати тільки до військової могутності, адже вона постійно зміщується 3 однієї сфери в іншу, наприклад із військової сфери в економічну. Варто відзначити і те, що в структуралістському підході розуміння сили поєднались здобутки як політичного реалізму, так і теорії взаємозалежності, а також впровадилося нове поняття - «структурна сила». Під структурною силою розуміється здатність міжнародних акторів забезпечити чотири соціальні потреби, які формують сучасну економіку: безпеку (враховуючи і оборонну могутність), знання, виробництво та фінанси. Основна мета такої сили полягає у її здатності: проникати через кордони, які раніше служили гарантією безпеки та захищали національну валюту і національну економіку; здійснювати вплив не перебіг та результат міжнародних переговорів; визначати «правила гри» в певній галузі міжнародних відносин. Американська дослідниця С. Стрендж під структурною силою розуміє «здатність визначати порядок речей, створювати рамки взаємодії держав, народів та корпоративних підприємств» і вважає США тією країною, яка в повній мірі може реалізувати таку силу $[1$, с. 16]. Сучасні глобалізаційні процеси (перш за все економічні) і впливають на появу нових дефініцій «сили».

Незалежно від обраної стратегії міждержавної взаємодії у політичному просторі, будь-яка 3 них й сьогодні базується на поняті «сили». Ця тенденція міжнародного життя пояснюється тим, що кожна держава піклується про реалізацію власних національних інтересів та веде пошук якісно нових ресурсів впливу на інших акторів міжнародних відносин. У цьому сенсі прикладом для наслідування є США, які не тільки використовують всі ресурси у міжнародних відносинах, але і моделюють та займаються розробкою нових у контексті тих змін, що відбуваються у світовому геополітичному просторі. Як яскравий приклад цьому - розробка концепції «м'якої сили».

У період «холодної війни» дві могутні світові держави СРСР і США ввели гонку озброєнь, нарощуючи свій військовий потенціал, але 3 іншого боку всі чудово усвідомлювали, що третя ядерна світова війна буде останньою на Землі, тому для запровадження свого впливу на інші держави світу і СРСР, і США використовували й інший інструментарій у своїй зовнішньополітичній діяльності. Дійсно, як стверджує професор Гарвардського університету Д. Най, особливість сучасної світової політики закладена не лише і не стільки «у тому, чия армія зможе отримати перемогу, а у тому, чий сюжет виграє» [9, с. 67]. Необхідно підкреслити, що і Радянський Союз 
у своїй зовнішньополітичній діяльності, використовував механізми реалізації саме концепції «м'якої сили» просуваючи свої соціалістичні цінності розвиваючим країнам і переваги своєї ідеології. Зрозуміло, що за цим стояла і військово-матеріальна допомога цим державам, але прагнення «бути привабливим» для цих країн та залучити у «свою орбіту» впливу мирним шляхом - очевидний факт, і це було на рівні державної політики. Таким чином, кінець «холодної війни» приніс дві важливі зміни, які пов'язані 3 міжнародними подіями. Перша зміна стосується політичної та військової динаміки. Біполярна міжнародна система вичерпала себе і світ змінився, перетворився на багатополярний, збалансований силовою системою. Ця зміна, загалом, стосується і міждержавних відносин, але необхідно було шукати та розробляти інші стратегії зовнішньополітичній діяльності.

Все це призводить до зміни природи самої сили, в основному роблячи «м'яку силу» більш потенційною. У сучасний час, незважаючи на видиму прагматичність міжнародного порядку денного, який акцентований на використанні державами військової сили як пріоритетного засобу забезпечення власної національної безпеки, не можна не помічати посилення впливу «м'яких» інструментів дії на систему міжнародних відносин. У сучасних умовах помітно зростає роль гнучких чинників, посилюється вплив політики «м'якої» сили у міждержавних відносинах. Сформульований відомим американським політологом Дж. Найєм у 1990 р. і розвинений ним у наступних роботах постулат про значущість і ефективність «м'якої сили» в зовнішній політиці держав, стає все більш актуальним. Треба звернути увагу, що під «жорсткою» силою Дж. Най має на увазі військову силу в сукупності із політичною, економічною і фінансовою потужністю, а «м'яку силу» він характеризує трьома основними компонентами: культурою, політичною ідеологією і зовнішньою політикою (дипломатією). «М'яка сила - це змусити інших хотіти результатів, які ви хотіли б отримати». Проте це «не те ж саме, що дія або вплив... М'яка сила - більше, ніж просто переконання, умовляння або здатність зробити що-небудь за допомогою аргументів, хоча все це $є$ важливими елементами цієї сили. М'яка сила - це також здатність приваблювати, і залучення часто веде до взаєморозуміння. Простіше кажучи, в поведінкових поняттях м'яка сила - це приваблива сила» $[8$, с. 69$]$.
В українському політичному дискурсі проблема сутності політики «м'якої сили» та можливості її використання Україною у зовнішньополітичній діяльності дуже актуальна. Водночас відкритим залишається питання щодо шляхів реалізації Україною політики «м'якої сили». На думку української дослідниці Н. Нікулішин, умовно можна виокремити три тематичні підходи до визначення змісту «м'якої сили». Перший орієнтується на культурну політику, враховуючи освіту та спорт, а два інших - демократичні цінності та публічну дипломатію у широкому $\dddot{i i}$ розумінні $[5$, с. 36$]$.

Дослідниця вважає, що очевидною є доцільність реалізації вітчизняної «м'якої сили» саме через культурну складову. Але, у зв'язку з військовим конфліктом з Росією $з$ початку 2014 р., необхідно переглянути саму перспективу використання політики «м'якої сили» України в міждержавних відносинах. Автор вважає, що весь потенціал цієї концепції вже вичерпаний, i $€$ необхідність обмеження використання цієї концепції (інформаційно та фінансово) за пріоритетом на іншу - «жорстку силу» (hard power). Мова йдеться про те, що політика «м'якої сили» повинна використовуватися для підвищення свого позитивного іміджу для інших країн. Зовнішньополітичний вектор України вже чітко визначений - це вступ до Свропейського Союзу і тому політика «м'якої сили» нашої держави направлена саме на країни європростору. Стосовно запровадження Україною цієї політики на країни колишнього СРСР, то нас очікує, по-перше, жорстока конкуренція з боку Росії (і в першу чергу в майбутньому стосовно Білорусі), та, по-друге, розбіжність із менталітетом нації тих країн, де було б актуальним проведення політики «м'якої сили» (насамперед країни Середньої Азії та Закавказзя) та специфічне їхнє відношення до демократичних цінностей.

Необхідно звернути увагу на інструментарій цієї політики, завдяки якому вона формується та використовується державою. «М'яка сила» грунтується на таких ресурсах, як культурно-ціннісна привабливість, привабливість національно-державної економічної моделі розвитку, привабливість політичної моделі [10, с. 36]. Стосовно України інструментарії привабливості економічної моделі розвитку не $\epsilon$ ефективними та поки ще безперспективні. Вторинні ефекти внутрішніх політичних та економічних потрясінь, анексії Криму та військових дій на Донбасі поширилися на більшість секторів вітчизняної економіки. Внаслідок цього поглиблю- 
ються існуючі диспропорції, прискорюються падіння ВВП, скорочення об'ємів промислового виробництва, виконаних будівельних робіт, зовнішньої торгівлі, зниження обсягів освоєння капітальних інвестицій тощо. Внутрішні ризики розвитку економіки України, головним чином, пов'язані з:

військовими діями на Донбасі, які призводять до скорочення виробництва у регіоні, погіршення умов залучення зовнішнього фінансування та зростання видатків бюджету на фінансування силових відомств і відновлення зруйнованої інфраструктури;

зростанням боргового навантаження на бюджет через необхідність фінансування дефіциту та заборгованості НАК «Нафтогаз», сформованої у минулі роки;

виснаженням міжнародних резервів, що ускладнює використання Національним банком інтервенцій в якості інструментів стримування зростання попиту на іноземну валюту, який виникає внаслідок панічних настроїв та спекулятивних атак [6].

Військовий конфлікт вкрай негативно діє на економічний сектор держави, і говорити стосовно його привабливості для інших країн регіонів «нашого» впливу просто не доводиться.

Культурно-ціннісна привабливість виражається у формуванні тренду країни. Мова йде про заклади культури та інформаційно-культурні проекти, які формують імідж України, і за допомогою яких держава впливає на образ та менталітет української нації за кордоном. На сьогодні в світі існує близько 200 країн, які різняться між собою своїм економічним, політичним і соціальним розвитком. Кожна держава має свій імідж, але імідж iï в світі $є$ таким, як бачать іiі інші держави, тобто як продемонструє себе та чи інша країна, так i сприймуть їі інші держави в світі. Необхідно зазначити, що попередне керівництво країни розуміло важливість формування позитивного іміджу за кордоном, за допомогою якого треба було проводити політику «м'якої сили». Цей факт підтверджує прийняття урядом «Концепції Державної цільової програми формування позитивного міжнародного іміджу України на 2013-2015 роки», в якому говориться, що «формування позитивного міжнародного іміджу України $є$ необхідною складовою внутрішніх соціально-економічних та суспільних перетворень, у тому числі успішної реалізації започаткованих владою системних реформ в Україні, підвищення рівня національної самосвідомості та зміцнення суспільної єдності». Цікавий факт: $є$ ідея утворення спеціалізованого державного орга- ну, на який покладаються функції із забезпечення на міжвідомчому рівні постійної, оперативної та скоординованої підготовки та розповсюдження у міжнародному інформаційному просторі позитивних відомостей про державу [2]. Але утворення спеціалізованого державного органу потребує значних видатків державного бюджету, тому головний напрям - це співпраця 3 різноманітними зарубіжними організаціями, у тому числі і у сфері культури. Для того, щоб задіяти весь іміджевий потенціал нашої держави, необхідні продумана державна інформаційна політика й чітко спланована брендінгова кампанія, а це потребує часу та значних фінансових витрат.

\section{Висновки.}

На думку автора статті, Україна вже використала у повному обсязі головний свій інструментарій політики «м'якої сили» - політичні цінності та привабливість політичної моделі. Основа «м'якої сили» України - громадянське суспільство. «Помаранчева революція» 2004 р. та «Революція гідності» 2014 р. - це знакові події сучасної України, події завдяки яким сформувався позитивний імідж країни за кордоном. Політолог А. Колодій вважає, що досягнення «Помаранчевої революціiі» 2004 р. - це, насамперед, кардинальні зміни у політичній свідомості народу, поява Громадянина; створення ситуації підконтрольності державних органів влади народу; прихід до влади нових людей і зміна правил політичної гри [3, с. 146]. Справді, головне досягнення подій того часу - поява Громадянина та його суб'єктності, і це потім проявилося у масових виступах українців на $\epsilon_{\text {в- }}$ ромайданах усієї країни, з метою висловити своє ставлення до політики влади 3 приводу майбутнього розвитку України в контексті євроінтеграції. На жаль, не політична еліта формує політичний імідж країни, а саме Український Народ 3 його громадянською позицією.

«Помаранчева революція» 2004 р. та «Революція гідності» 2014 р. - це знакові події сучасної України та головний інструментарій стратегії «м'якої сили». Ці події сформували позитивний імідж України в країнах євро простору, і $є$ необхідність обмеження використання цієї концепції (інформаційно та фінансово) та надавати пріоритет іншої - «жорсткої сили». Концепція «м'якої сили» ефективна тільки в країнах зі значним військовим та економічним потенціалом. Події в Україні показують, що для забезпечення своєї національної безпеки для держав «другого ешелону» пріоритетним $є$ формування військової могутності, яка завжди служила основним показником сили і престижу держави. 


\section{БІБІЛІОГРАФІЧНІ ПОСИЛАННЯ}

1. Капітоненко М. Силовий фактор у міжнародних відносинах : Парадигми, теорії, концепції / М. Капітоненко // Вісник Київського Національного університету імені Тараса Шевченка: Міжнародні відносини. - 2006. - № 33/34. - С. 13-18.

2. Концепція Державної цільової програми формування позитивного міжнародного іміджу України на 2013-2015 роки. Режим доступу : http://govuadocs.com.ua/docs/ index-19943079.htm.

3. Коротков Д. С. Політична еліта України: становлення та розвиток у виборчому процесі: монографія / Д. С. Коротков Харків: Вид-во ХНЕУ, 2012. -207 с.

4. Нікулішин Н. «Сила» в умовах сучасної світової політики: трансформація змісту / Н. Нікулішин // Слов’янський вісник. - 2012. - Вип. 14. - С. 193195.

5. Нікулішин Н. Основні підходи до розкриття змісту поняття «м’яка сила» у сучасній вітчизняній науці / Н. Нікулішин // Українська національна ідея: реалії та перспективи розвитку. - 2014. - Вип. 26. - С. 32-37.

6. «Щодо тенденцій розвитку економіки України у 2014-2015 pp.» Аналітична записка - Режим доступу: http://www.niss. gov.ua/articles/1635/.

7. Пономарева Е. Г. Секреты «цветных революций» Современные технологии смены политических режимов / Е. Г. Пономарева // Свободная мысль. - 2012. - № 3/4. - С. 4359.

8. Филимонов Г. Ю. Неофициальная внешняя культурная политика как компонент «мягкой силы» США / Г. Ю. Филимонов // США-Канада: экономика, политика, культура. - 2007. - № 4. - С. 69-82.

9. Филимонов Г. Ю. Актуальные вопросы формирования российского потенциала «мягкой силы» / Г. Ю. Филимонов // Вестник РУДН : Политология. - 2012. - № 1. - С. 6782.

10. Чихарев И. В. К вопросу о соотношении стратегий «мягкой силы» и «разумной силы» в мировой политике / И. В. Чихарев, О. В. Столетов // Вестник Московского университета. Серия 12. Политические науки. - 2013. - № 5. - С. 26-43.

\section{REFERENCES}

1. Kapitonenko, M. (2006). Sylovyi faktor u mizhnarodnykh vidnosynakh : Paradyhmy, teorii, kontseptsii [Power factor in international relations: Paradigms, theories, concepts]. Visnyk Kyivskoho Natsionalnoho universytetu imeni Tarasa Shevchenka: Mizhnarodni vidnosyny, 33/34, 13-18 [in Ukrainian].

2. Kontseptsiia Derzhavnoi tsilovoi prohramy formuvannia pozytyvnoho mizhnarodnoho imidzhu Ukrainy na 2013-2015 roky [The concept of the state target program creating a positive international image of Ukraine for 2013-2015]. Retrieved from: http:// govuadocs.com.ua/docs/ index-19943079.htm [in Ukrainian].

3. Korotkov, D.S. (2012). Politychna elita Ukrainy: stanovlennia ta rozvytok u vyborchomu protsesi [The political elite of Ukraine: formation and development of the electoral process:monograf]. Kharkiv [in Ukrainian].

4. Nikulishyn, N. (2012). «Syla» v umovakh suchasnoi svitovoi polityky: transformatsiia zmistu [«Power» in today’s world politics: the transformation of content]. Slovianskyi visnyk, 14, 193-195 [in Ukrainian].

5. Nikulishyn, N. (2014). Osnovni pidkhody do rozkryttia zmistu poniattia «miaka syla» u suchasnii vitchyznianii nautsi [Basic approaches to disclosure of the meaning of «soft power» in modern domestic scienc]. Ukrainska natsionalna ideia: realii ta perspektyvy rozvytku, 26, 32-37 [in Ukrainian].

6. Shchodo tendentsii rozvytku ekonomiky Ukrainy u 2014-2015 rr.» Analitychna zapyska [The trend of development of Ukraine in 2014-2015: Analytic note]. Retrieved from: http://www.niss.gov.ua/articles/1635/ [in Ukrainian].

7. Ponomareva, E.G. (2012). Sekretyi «tsvetnyih revolyutsiy» Sovremennyie tehnologii smenyi politicheskih rezhimov [Secrets of «color revolutions» Modern technologies of political regime change]. Svobodnaya myisl, 3/4, 43-59 [in Russian].

8. Filimonov, G.Yu. (2007). Neofitsialnaya vneshnyaya kulturnaya politika kak komponent «myagkoy silyi» SShA [Informal foreign cultural policy as a component of «soft power» of the US]. SShA-Kanada: ekonomika, politika, kultura, 4, $69-82$ [in Russian].

9. Filimonov, G.Yu. (2012). Aktualnyie voprosyi formirovaniya rossiyskogo potentsiala «myagkoy silyi» [Actual issues of Russian potential «soft power»]. Vestnik RUDN: Politologiya, 1, 67-82 [in Russian].

10. Chiharev, I.V., \& Stoletov, O.V. (2013). K voprosu o sootnoshenii strategiy «myagkoy silyi» i razumnoy silyi» v mirovoy politike [The relationship between strategies of «soft power» and «smart power» in world politics]. Vestnik Moskovskogo universiteta. Seriya 12. Politicheskie nauki, 5, 26-43 [in Russian].

\section{Коротков Дмитро Сергійович}

Кандидат політичних наук, доцент

Харківський Національний Економічний Універ-

ситет імені С. Кузнеця

61166, м. Харків, просп. Науки, 9-А

Email: Dmytro.korotkov@hneu.net

Цитування: Коротков Д. С. Концепція «м'якої сили» в контексті зовнішньополітичної стратегії України / Д. С. Коротков // Науково-теоретичний альманах «Грані». - 2018. - Т. 21. - № 9. - С. 131-136.

Citation: Korotkov, D.S. (2018). Kontseptsiia «miakoi syly» v konteksti zovnishnopolitychnoi stratehii Ukrainy [The concept of «soft power» in the context of Ukrainian strategy of foreign policy]. Scientific and theoretical almanac «Grani», 21(9), 131-136.

Стаття надійшла / Article arrived: 03.08.2018

\section{Korotkov Dmytro}

$\mathrm{PhD}$ in political science, Associate Professor

S. Kuznets Kharkiv national university of economics 9-A, Nauky avenue, Kharkiv, 61166, Ukraine 